Proceeding Paper

\title{
Analyses Regarding Possible Effects of Electromagnetic Waves Emitted on Agricultural Productions ${ }^{\dagger}$
}

\author{
Lavinia Popescu and Adela Sorinela Safta *(1)
}

check for updates

Citation: Popescu, L.; Safta, A.S. Analyses Regarding Possible Effects of Electromagnetic Waves Emitted on Agricultural Productions. Environ. Sci. Proc. 2021, 8, 43. https:// doi.org/10.3390/ecas2021-10701

Academic Editor: Anthony R. Lupo

Published: 22 July 2021

Publisher's Note: MDPI stays neutral with regard to jurisdictional claims in published maps and institutional affiliations.

Copyright: (c) 2021 by the authors. Licensee MDPI, Basel, Switzerland. This article is an open access article distributed under the terms and conditions of the Creative Commons Attribution (CC BY) license (https:/ / creativecommons.org/licenses/by/ $4.0 /)$.

\author{
Doctoral School Economics II, Bucharest University of Economic Studies, 010374 Bucharest, Romania; \\ popesculavinia14@stud.ase.ro \\ * Correspondence: saftaadela19@stud.ase.ro \\ + Presented at the 4th International Electronic Conference on Atmospheric Sciences, 16-31 July 2021; Available \\ online: https:/ / ecas2021.sciforum.net.
}

\begin{abstract}
This paper aims to highlight in a unique way the effects on sustainable agricultural systems due to the global growth of the development of the communications system. From the very beginning, we discussed the disruptions of climate change and, in particular, the risk of disaster, which causes long academic debates regarding electromagnetic radiation. During the study, we conducted empirical research using the wide range of receptors and a detailed determination bridge; we used quantitative methods to collect the processes and analyze the data and information incorporated to formulate observations and conclusions. The aim of this paper is to highlight an assessment for obtaining an answer to the possible causes of climate disturbances in agriculture, given the epistemic uncertainty. Mainly, we will reflect on the effects that interfere with the level of electromagnetic radiation produced by antennas. Opening advanced technologies with new satellite capabilities is expensive, so now, the density of high-power data transmissions useful in digital agriculture is the technical solution of operators. Our empirical research experimentally analyzes the data we collect in the statistical monitoring of electromagnetic waves, investigating to what extent the electromagnetic radiation affects agricultural systems concerned with trying to sequester $\mathrm{C}$ from the soil and reduce greenhouse effects. The paper defines and presents the evolution of the impact of new technologies developed in order to facilitate the implementation of intelligent agricultural solutions, admitting that the opening of new technologies facilitates the creation of the economically and socially interconnected global community (McLuchan, 1973). Taking into account the intensification of the use of digital agriculture, the analysis proposed for research is a topic that needs updating, and in this sense, it is necessary that this research be analyzed from environmental perspectives.
\end{abstract}

Keywords: electromagnetic waves; agricultural; land-atmosphere interactions

\section{Introduction}

As highlighted in specialized studies according to Leal Filho et al. (2017), RodrigoComino et al. (2018), and the most recent being Anderson and Mammides (2020), the abandonment of agricultural land creates cause-effect relationships on ecosystem services, in this case an increased carbon storage, affecting sustainability [1-3].

The agri-environment system must be included in the set of sustainability targets, we believe, this being possible with the help of the technique in a global interconnection as claimed by S.D. Neill (1973) [4].

Therefore, regarding the correlation of economic interests in terms of adaptation to new trends in the digitalization of agricultural systems as a field, in general, it would be desirable to agree with these systems of sustainability not only of the environment that is now at the forefront but as a whole or as a major challenge to the effects of sustainability in the environment, including technique. When we talk about technology, we look back 
decades before 1997, when we did not have wireless global communication, and so, the systematization of the integration of this service would not predict the effects and benefits of digitization but at what cost, how electromagnetic waves are felt, and whether it can affect the environment to some extent.

Of course, the benefits brought in the agricultural systems cannot suppress the exigency of analyzing the variations of the electromagnetic waves in relation to the environment, the analysis of the disasters being a topic of interest especially chosen from the perspective of the more aggressive atmospheric and climatic changes.

Starting from the need to digitize agriculture, today, we have an intrinsic need to use digital technology and not just the Internet. More and more intelligent applications help us to receive real-time information about the weather, when to apply fertilizers, where to get them, and especially what quantities and how to apply them with drones.

All these concerns that indicate a foreshadowed risk in digitalized agriculture help us design an effective approach to develop the digitalization system in agriculture as a major challenge. Achieving the decarbonization of agriculture involves both costs and emerging strategies for quantifying and forecasting them. Therefore, in our opinion, when we examine the adaptation of the digitalization of the agricultural economy, we predict in part some indirect effects on agricultural systems, such as electromagnetic waves, radiation emitted precisely to find and propose solutions for the future of rural development for sustainability.

However, a higher level of use of the digitalization of agriculture and the economy should outline a strategy to address the risks of new technologies, and here, we discuss the electromagnetic waves and their influences on agricultural production without omitting atmospheric changes.

\section{Evolutions Regarding Greenhouse Gas Emissions in Agriculture}

Romania, similar to the rest of the world, is facing the problem of climate change and environmental degradation. The present analysis derives from the growing concern to integrate the digitalization of agriculture among the new concepts more widely in all areas of Romania facing serious socioeconomic challenges posed by the transition to a climate-neutral Union economy by 2050 [5].

These dual challenges require a closer look at the related risks that we need to know about integrating the digitalization of agriculture and how we can avoid some programming effects. There is more and more talk about pressure in electrical systems, how exposure to electromagnetic waves actually works, and why we need high-performance systems; these questions enable us to answer to how much we will achieve a programmed digitization; subsequently, the more we will be able to use these systems for the benefit of the community in which we use them to ensure a sustainable development in the agri-environment system.

The high frequency of climatic phenomena has caused more and more damage lately. In the last two decades, Romania has faced floods on the one hand, but also droughts, which are in response to climate change, the wind being again a frequent atmospheric phenomenon.

In addition, the territory of our country presents a risk of $13 \%$ of the total flood area, being qualified as exposed to this phenomenon among EU countries as revealed by the OECD 2020 [6].

In view of this evidence, a concern to increase sustainability includes the need for production models aimed at digitizing agriculture in order to avoid, against the background of economic growth, the effects leading to maintaining or even increasing the level of GHG emissions not only in agriculture but in general.

This fragment provides an overview of the growing global trend in terms of the effects of electromagnetic waves emitted by telephony systems and GSM antenna transmission capsules. The first part describes the impact of carbon emissions in Romania in the agricultural sector. It also presents the key elements of the disaster risk management 
framework for agriculture, which include, among others, the identification of these risks, control, and awareness.

Most of the increasingly common natural disasters have caused hazards and have been linked to weather and climate. However, there are other disasters that cannot be quantified and are often ignored by ignorance, electromagnetic waves, and their effects on the environment.

Despite the good quality natural soil resources, agriculture in Romania is characterized by a source of $17.4 \%$ of total greenhouse gas emissions in the country, but it is ranked last in the ranking of intensity of emissions from agriculture at thet EU level, due to the low productivity of the sustainable agriculture sector, according to Girardin (2012) [7].

The reorientation of the agricultural design mechanisms determined by the rise of the use of agricultural digitization leads to rapid counterbalancing of the current situation as soon as the efficiency of agriculture will increase. Thus, both the reduction of GHG emissions in agriculture and the adaptation through agricultural processes to climate change are both important factors, and maintaining their balance is a concern.

As we highlight in Figure 1, greenhouse gas emissions show long-term evolutions, the resulting diagram deciphering only forecasts on the reference field of agriculture.

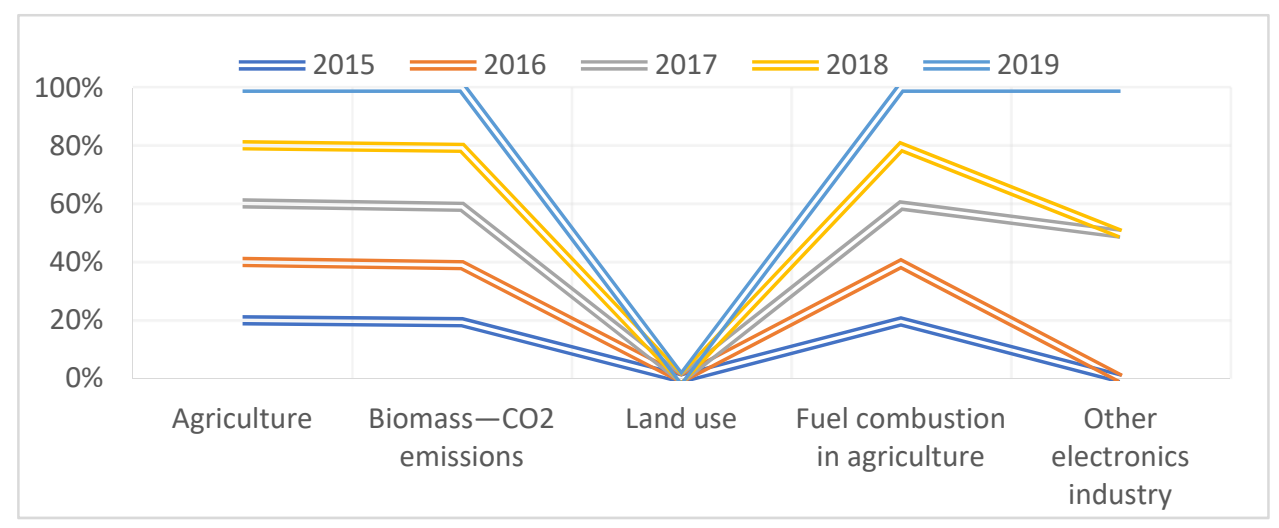

Figure 1. Evolution of greenhouse gas emissions. Source: Data CEE Eurostat (2020).

These emissions are expected to be a response to climate change in relation to favorable critical interdependencies, including agriculture, as shown in Table 1.

As can be seen in Table 1, there is no concrete evidence of pollution in the electronics industry, although the greenhouse gas emissions produced by this electronics industry are obvious, this being another reason to create some premises for research into the effects of electromagnetic waves emitted in the atmosphere.

Another cause of the reduction of the agricultural land area is represented by the effects of rainwater management and arrangements of protection areas (Aznar-Sánchez et al. (2019) [8].

Thus, on the whole, the climate and the changing weather phenomena that have become more and more aggressive by their extent show the weight that farmers face on large commercial agricultural holdings. Scenarios are being made worldwide regarding the effects of climate change here and the Green Deal approach in order to prevent the effects on farmers in general and individually [9].

Given that large farms usually have a highly specialized production, such as cereals and oilseeds, they are particularly vulnerable to the impact of frequent and long-term droughts, which affect their production and profit.

The creation of agribusiness and forestry systems with strong incentives for soil carbon growth could be at the center of climate stabilization, as indicated by Mazza (2007) [10].

Therefore, the integration of digital systems and agricultural ecosystems can be seen as a lever for counting electromagnetic waves from mobile data sources; see the data presented in Figure 2. 
Table 1. Greenhouse gases $\left(\mathrm{CO}_{2}, \mathrm{~N}_{2} \mathrm{O}\right.$ in $\mathrm{CO}_{2}$ equivalent, $\mathrm{CH}_{4}$ in $\mathrm{CO}_{2}$ equivalent, $\mathrm{HFC}$ in $\mathrm{CO}_{2}$.

\begin{tabular}{|c|c|c|c|c|c|c|}
\hline AIRPOL & 2015 & 2016 & 2017 & 2018 & 2019 & of EU27_2020 \\
\hline UNIT & $\begin{array}{l}\text { Thousand } \\
\text { Tonnes }\end{array}$ & $\begin{array}{l}\text { Thousand } \\
\text { Tonnes }\end{array}$ & $\begin{array}{l}\text { Thousand } \\
\text { Tonnes }\end{array}$ & $\begin{array}{l}\text { Thousand } \\
\text { Tonnes }\end{array}$ & $\begin{array}{c}\text { Thousand } \\
\text { Tonnes }\end{array}$ & \\
\hline Agriculture & $432,006.72$ & $432,829.39$ & $435,960.82$ & $431,462.42$ & $427,601.91$ & in EU27_2020 \\
\hline Biomass $-\mathrm{CO}_{2}$ emissions & $546,476.8$ & $554,469.91$ & $566,450.28$ & $573,491.71$ & $584,523.58$ & in EU27_2020 \\
\hline $\begin{array}{l}\text { Land use, land use } \\
\text { change, and forestry } \\
\text { (LULUCF) }\end{array}$ & $-292,346.11$ & $-291,305.09$ & $-291,305.09$ & $-291,305.09$ & $-233,948.9$ & in EU27_2020 \\
\hline $\begin{array}{l}\text { Fuel combustion in } \\
\text { agriculture, forestry and } \\
\text { fishing }\end{array}$ & $79,133.57$ & $79,751.06$ & $80,490.11$ & $81,557.74$ & $81,822.57$ & in EU27_2020 \\
\hline $\begin{array}{l}\text { Other electronics } \\
\text { industry }\end{array}$ & - & - & 1.09 & - & 1.1 & in EU27_2020 \\
\hline
\end{tabular}

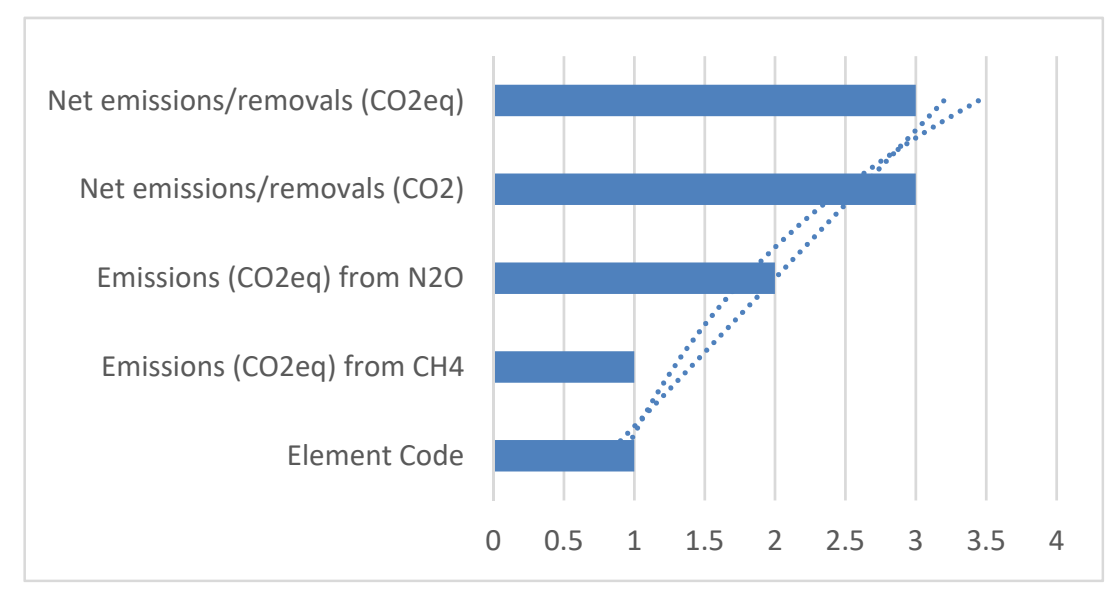

Figure 2. Count of net emissions/removals $\left(\mathrm{CO}_{2} \mathrm{eq}\right)$. Source: Author's own from data CEE Eurostat (2015).

The soil can degrade depending on many objects (Andrei A. et al. (2015)) [11].

In fact, there is an accumulation of characteristics that can create the premises of agricultural systems designed as ecosystems included in the forecast environment with future orientations that are resistant and adaptable to progress.

The paper brings as a novelty some characteristics of agricultural ecosystems by highlighting the monitoring and ash design of electromagnetic wave sources in the cells of mobile data antennas.

\subsection{Soil and Electromagnetic Waves}

Impact forecasts are expected, with climate change, weather, and climate disasters to continue to increase in frequency and severity (IPCC, 2012 [12]). Due to this exposure, there is a general climate sensitivity in agriculture (FAO, 2016 [13]).

There are also premises for pests and diseases of plants and animals to increase due to climate change, atmospheric phenomena meaning that the design of digitized agricultural processes takes precedence to prevent disasters, according to the FAO (2005) [14].

The highlighting in Figure 3 of the variation of agricultural producers at the EU level shows a progressive increase, although this increase has no cause in increasing production but rather related agricultural services, agricultural systems being closely related to the evolution of digitalization of non-agricultural services, such as distribution, transport, and the sale of agricultural products and fertilizers used in agriculture. 


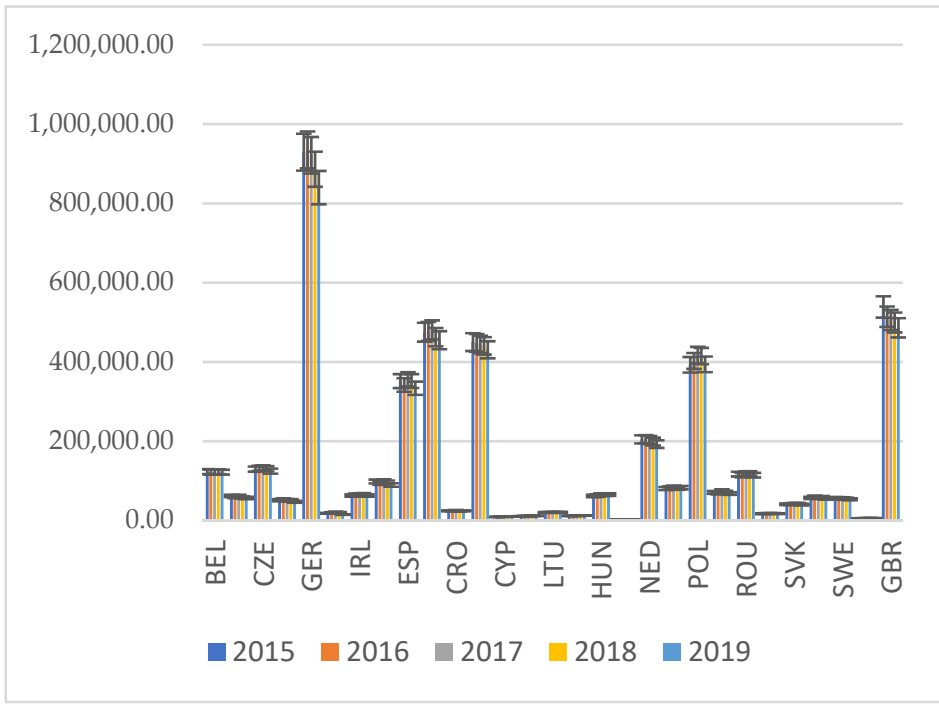

(a) Greenhouse gases emission state $27 \mathrm{UE}$

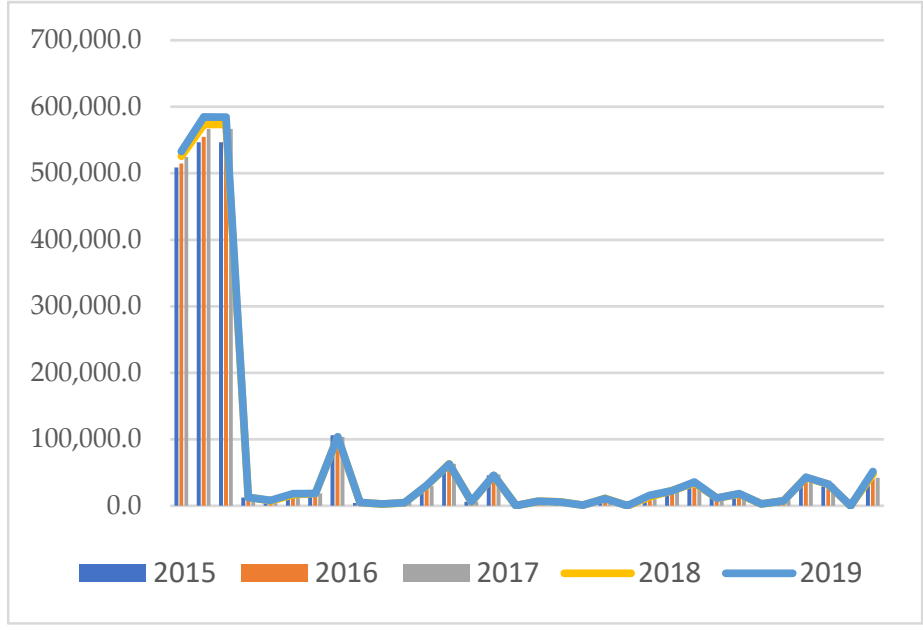

(b) Greenhouse gas emissions by source sector

Figure 3. Greenhouse gas emissions by source sector (source: EEA) [env_air_gge]. Source: Author's own from data Eurostat (2015-2019).

However, as shown in Figure 4, which highlights the population in EU agricultural systems, the population compared to the number of agricultural enterprises we observe increases in the active population. The reduced productivity is attributed to the large proportion of subsistence farms without including another important factor, namely the risk of disasters.

At this time, there is no global study on the impact of different types of disasters on agriculture. However, scientific research must continue to bring to the surface of each economic and agricultural system some effects of customs related to the adaptation of digitization, the effects of electromagnetic waves, and whether they can have an impact through effects such as radiography disasters, being a kind of reverse effect of greenhouse effects. 


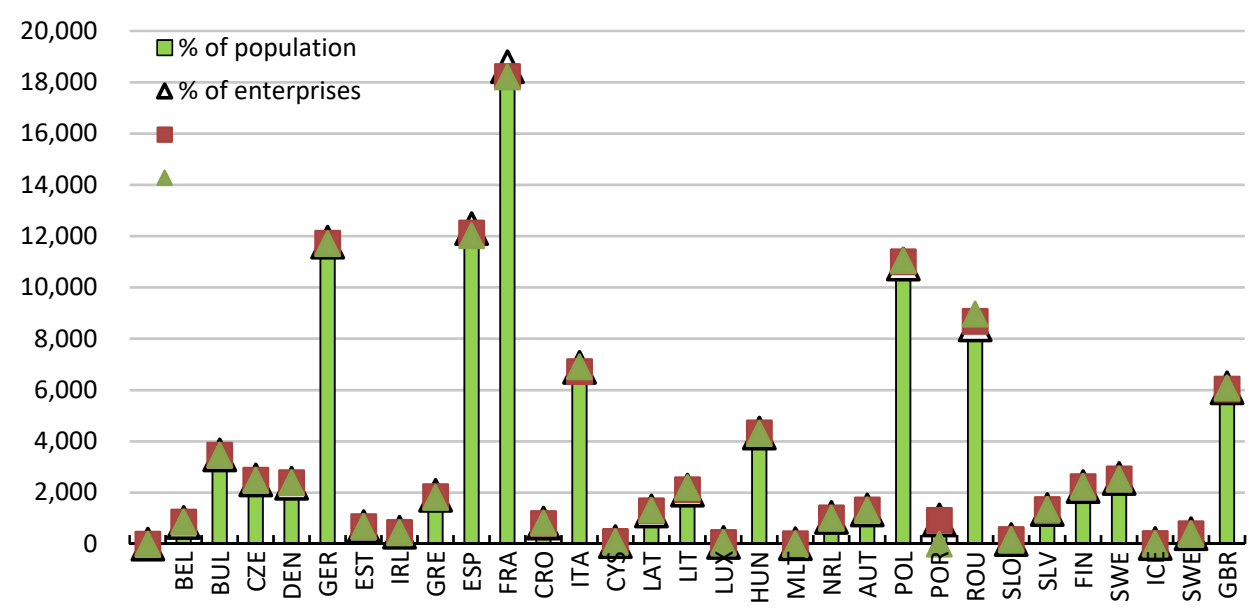

Figure 4. Highlighting the population in EU agricultural systems. Source: Author's own from data CEE Eurostat (2020).

\subsection{Disasters and Air Pollution}

Generic so-called natural disasters are a major cause of food insecurity, as reported by the FAO-WFP (2020) [15].

The impact of these disasters extends beyond the economic sphereby reducing the availability of sustainable food, limiting the reduction and/or loss of agricultural land, and, as the case may be, affecting the nutritional qualities of plants, vegetables, and fruits by exposure to radiation or electromagnetic waves.

Thus, another type of disaster can lead to imbalances in food stability at any time, as stated by Popescu (2021) [16].

The air pollution highlighted in Table 2 (AIRPOL) considered SOx, $\mathrm{NOx}, \mathrm{NH}_{3}$, NMVOC, PM10, PM2.5, Cd, Hg, As, Cr, Cu, Ni, Se, Zn, and Pb, while through the source sector for air emissions, the classifications are under the LRTAP Convention. The Convention on Long-range Transboundary Air Pollution was the first legally binding international instrument to address air pollution issues on a broad regional basis. It was signed in 1979 and entered into force in 1983. Since then, it has been extended by eight specific protocols [17].

Table 2. Air pollutants by source sector (source: EEA) European Union-28 countries (2013-2020) and Iceland under the Kyoto Protocol [env_air_emis].

\begin{tabular}{cccccc}
\hline AIRPOL & $\mathbf{2 0 1 4}$ & $\mathbf{2 0 1 5}$ & $\mathbf{2 0 1 6}$ & $\mathbf{2 0 1 7}$ & $\mathbf{2 0 1 8}$ \\
\hline UNIT & Tonne & Tonne & Tonne & Tonne & Tonne \\
\hline $\begin{array}{c}\text { Non-methane volatile } \\
\text { organic compounds * }\end{array}$ & $7,175,978$ & $7,131,236$ & $7,090,428$ & $7,156,077$ & $7,014,421$ \\
Particulates $<10 \mu \mathrm{m}$ & $2,039,964$ & $2,050,731$ & $2,024,952$ & $2,030,918$ & $1,988,686$ \\
Particulates $<2.5 \mu \mathrm{m}$ & $1,310,984$ & $1,321,946$ & $1,303,169$ & $1,304,387$ & $1,254,688$ \\
Nitrogen oxides & $8,226,311$ & $8,047,481$ & $7,749,410$ & $7,596,656$ & $7,286,691$ \\
Sulphur oxides & $2,851,109$ & $2,677,623$ & $2,233,997$ & $2,189,893$ & $2,043,268$ \\
Ammonia & $3,839,232$ & $3,887,048$ & $3,900,696$ & $3,919,805$ & $3,858,921$ \\
\hline
\end{tabular}

Source ${ }^{*}$ European Environment Agency (EEA). National total for the entire territory (based on fuel sold).

Directive 2001/81/EC of the European Parliament and of the Council on national emission ceilings for certain pollutants (NEC Directive) sets upper limits for each member state for certain pollutants responsible for acidification, eutrophication, and ground-level ozone pollution [18].

Under the EU inventory system, the European Environment Agency and the European Center for Air Pollution and Climate Change Mitigation are responsible for compiling the annual EU inventory. 
By way of example, we have highlighted in Figure 5 countries considering the annual inventory of pollution in the area covered by its member states. Regarding pollutants to non-methane volatile organic compounds, the leaders are Germany, 1,196,457; Italy, 940,101; Poland, 708,249; France, 662,961; Spain, 572,369; Romania, 241,860; another example is particulates < $10 \mu \mathrm{m}$ pollutant: Gr 1,202,279; Pol 761,712; Fr 749,007; Sp 698,483; Italy 669,157; Romania having 225,378.

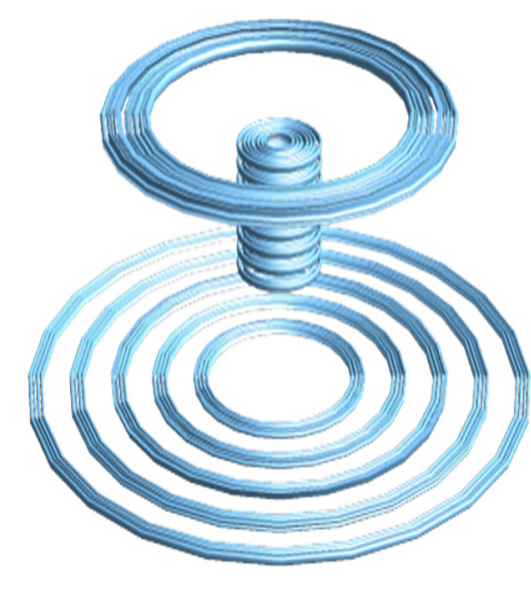

(a) Virtual

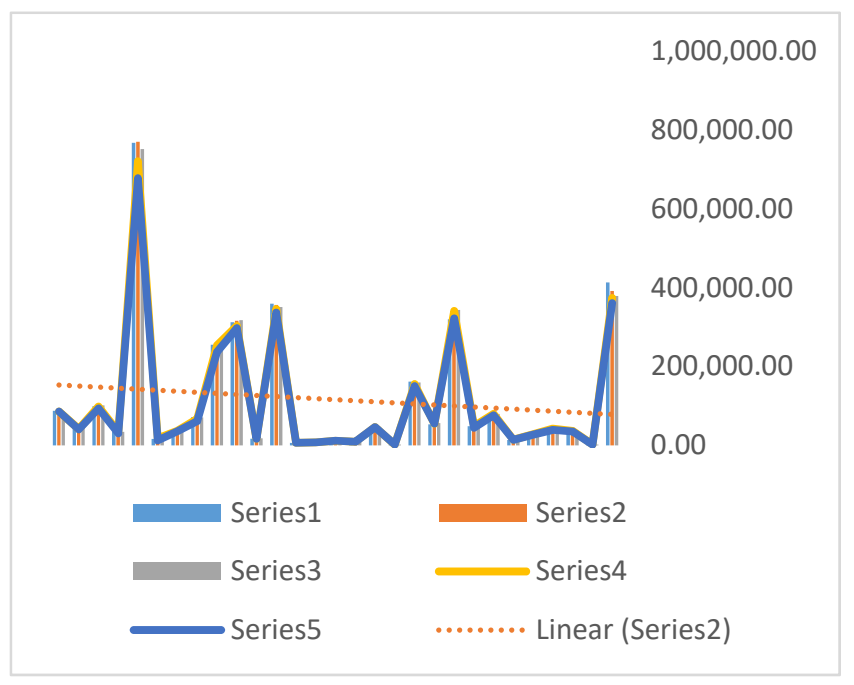

(b) global

Figure 5. Highlighting pollutants (a) and (b) in agricultural systems UE. Source: Author's own from data of the European Environment Agency (EEA).

\section{Results}

Agricultural Ecosystems and Electromagnetic Waves

The aim of the paper points to the progress of digitalization of agriculture with increased risks of rising electromagnetic waves in large areas of development and presents a collection of data to obtain an answer to possible causes for climate disturbances in agriculture, given the epistemic uncertainty. Several properly identified statistical distributions allow the acceptable approximation of the frequent values of electromagnetic waves but do not make a direct connection with the effects on agricultural ecosystems whether we are talking about animal farms or plantations. The scattering of GSM cells as well as radiation verification can be the subject of a more careful analysis by exploring the data as a consequence of the epistemic uncertainty and by defining an area of uncertainty both for the recorded data and for the extrapolated values. Here, we consider some upper and lower values of the uncertainty intervals as limits for achieving a compatible interdependence between data on a given area.

Due to the epistemic uncertainty, the statistical estimates thus belong to a range of uncertainty, which will depend on the spread of the analyzed statistical distributions.

For the present paper, instead of looking for the best distribution function, the uncertainty interval was used to define the reasonable limits of these limits; however, since there are not enough data, the monitored points are random.

The best solution to match the empirical data is the spatial variability and duration of a series of monitoring of available electromagnetic waves. Moreover, the recorded data are subject to epistemic uncertainty due to incomplete knowledge of the system of electromagnetic wave effects. Before any statistical analysis, the data must be verified for mutual independence and identical distribution, homogeneity, and lack of trend data of the sample used at a frequency of 1 to three months and one year as seen in Figures 6-9. 


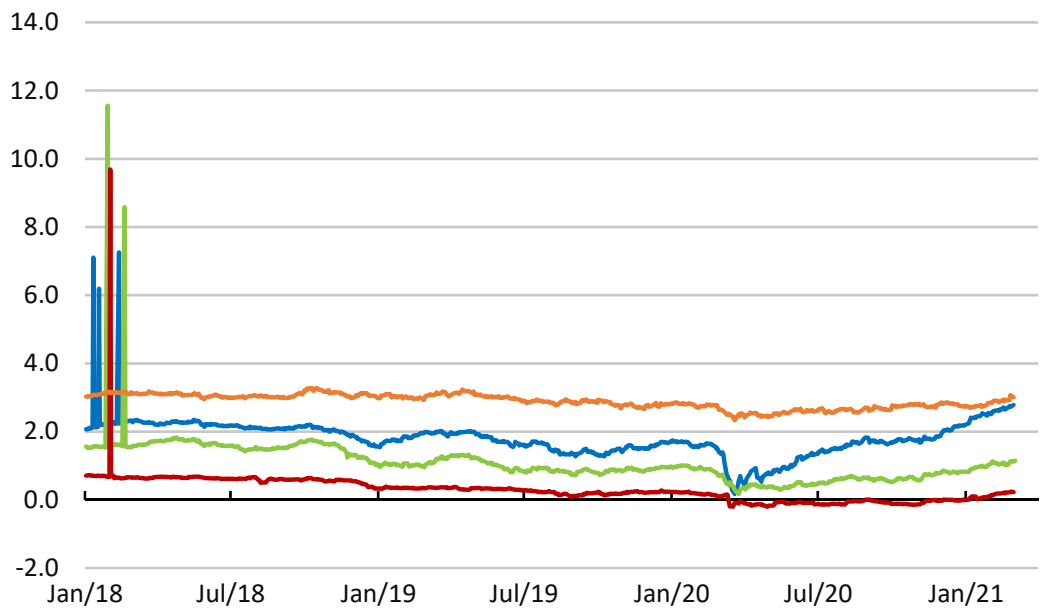

Figure 6. Electromagnetic field monitoring. Source: Author's own from data of the European Environment Agency (EEA).

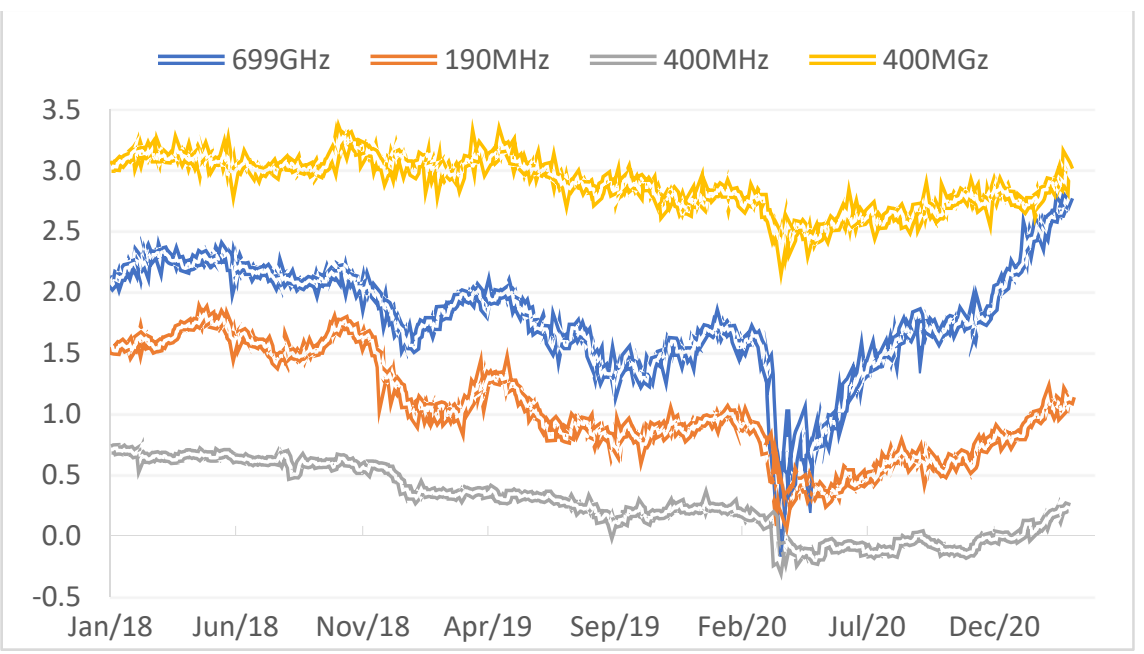

Figure 7. Electromagnetic field monitoring. Source: Author's own from data of the European Environment Agency (EEA).

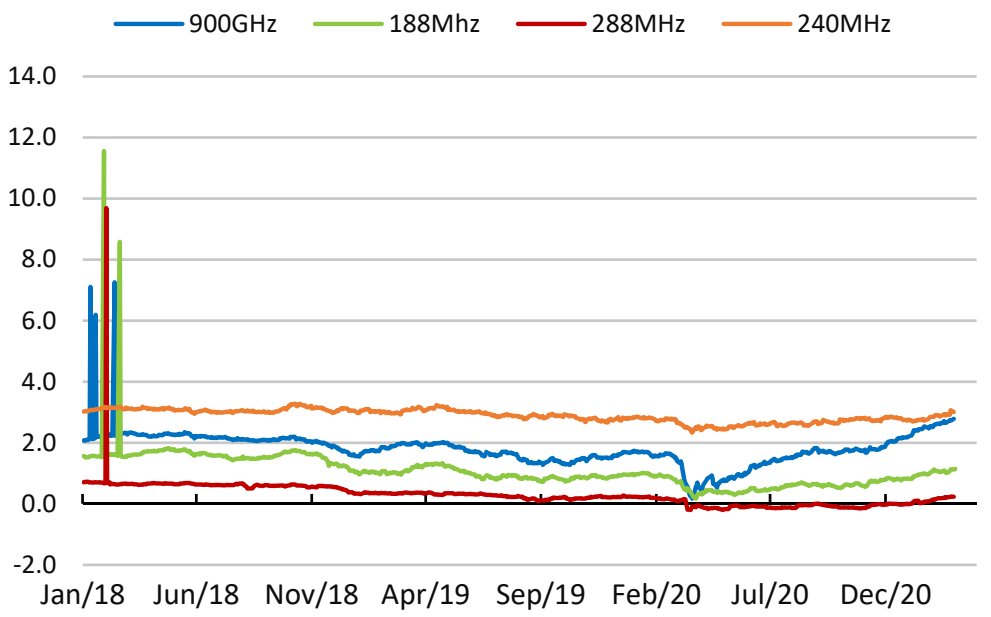

Figure 8. Electromagnetic field monitoring, Source: Author's own from data of the European Environment Agency (EEA). 


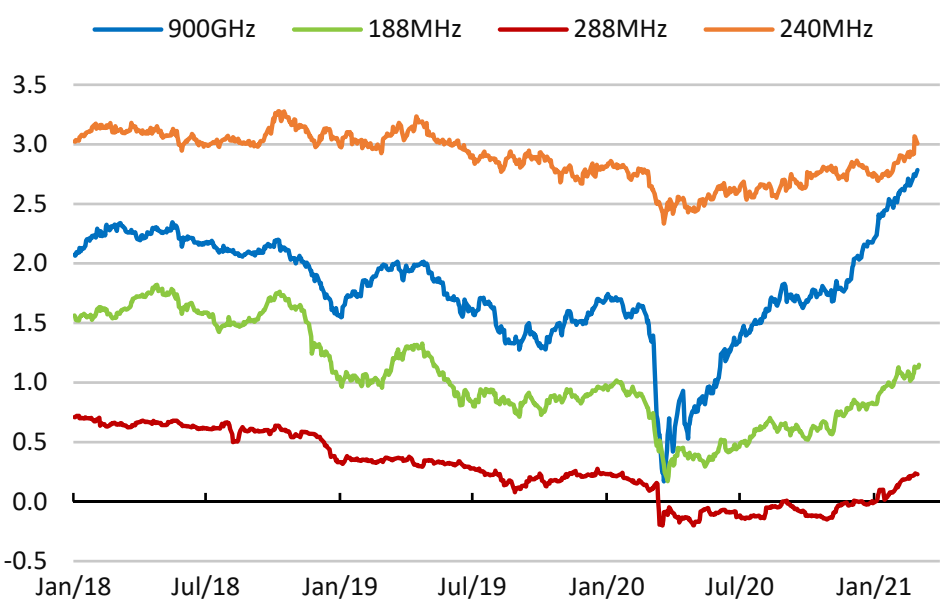

Figure 9. Electromagnetic field monitoring. Source: Author's own from data of the European Environment Agency (EEA).

The stationary nature of the data, although in most cases, implicitly assumed, is questionable due to land cover and land-use changes or climate change. Depending on the purpose and the available data, the analysis is supported by the way in which it would be good to distribute the radars for checking the electromagnetic fields compared to the proximity of agricultural systems for a proper management of the risk of high electromagnetic field pressure or why it is not managed with values exceeding the allowed limits, really known, as well as proper planning and design in the future so as not to affect agricultural systems, this being in fact a different kind of pollution.

Exposure to the electromagnetic field is regulated by law, according to the practices adopted in the European Union. Thus, it is regulated according to Recommendation 1999/519/EC on limiting the exposure of the general population to electromagnetic fields (from $0 \mathrm{~Hz}$ to $300 \mathrm{GHz}$ ), but in agriculture, they are not monitored; measurements on the level of electromagnetic field emitted by antennas used in frequency bands up to seven present for 5G technology, etc. are important data in the case of sustainable systems.

The present research adds to the possible causes of disturbance or risk of absorption of $C$ in the soil, due to electromagnetic causes from various sources, but the subject is not evaluated in depth because both statistical data for periods of time and measurement solutions are missing in Figures 6-9; we managed to extract the evaluation of a localized example of monitoring an electromagnetic field.

The lack of measuring stations at the level of agricultural farms is complicated by the lack of information, but the present exercise shows the need for information in order to discover with greater precision the effects of electromagnetic fields at the level of agricultural crops and plantations.

As indicated in Figures $7 \mathrm{a}$ and $8 \mathrm{~b}$, there is a suspicion that there are surges or shocks as we call them, which determine much lower values in Figure 3 and much higher values in Figure 8 at the level of monitored electromagnetic waves. The investigation must continue and use other levers to determine on the basis of scientific data the effects of these up or down electromagnetic waves and what are in fact the real causes. In the data extracted from the database, we alternately evaluated information on electromagnetic waves to look for a connection between the climate zone.

From the technical data considered in the research, GSM cells are emitting factors of electromagnetic fields at low levels. Mobile telephony operates through electromagnetic fields with frequencies between $9 \mathrm{kHz}$ and $300 \mathrm{GHz}$; see Co-communiqué Communications Regulatory Agency (2020) and Amparo Lázaro (2016) [19].

Antennas typically operate at much higher frequency radio frequencies than cell phones. According to Wikipedia data, the level of the electromagnetic field in front of the antenna decreases very strongly as the distance from the antenna increases, being negligible behind it. Therefore, we can say that at $6 \mathrm{~m}$ from an antenna, we are in the safe 
area where the level of the electromagnetic field is lower than the reference level stipulated in the norms, regardless of its power and type [20].

In addition, research indicates that soil is a prime example of the need to think globally and act locally to better find the need to harmonize methodologies for researching the processes underlying the functions of the solution (e.g., the role of soil in global CO2 accounting and biodiversity protection, spatial and temporal changes in soil processes).

\section{Conclusions}

The big challenge, as I said before, is the impact of climate change on agricultural production systems.

Among the objectives pursued were the protection and sustainable use of digitized agricultural processes to protect as efficiently as possible the soil, biodiversity, and human resources in agriculture.

Failure to protect the soil will undermine long-term sustainability and competitiveness in Europe. Since soil is related to air and water, in this symbiosis, it is possible to regulate soil quality and the implications arising from it. In addition, they can have a significant impact on the prediction of agricultural processes that are obviously related to digitization. This is due to the risks of disasters. Thus, in our opinion, the electromagnetic fields can generate a fluctuation in the soil level, preventing the contamination of the soil or reducing its level, which is a necessary complement to the measures to ensure the safety of feed and food. The idea of approaching this research problem and conducting research from the perspective of digitizing agriculture that agricultural systems adopt contributes to supporting the economy; research on this topic has emerged as a result of detailed study of the literature.

Concern for the good of the economy being an intrinsic component of the way processes evolve in farms and agriculture must not omit that electromagnetic waves must be further investigated in terms of atmospheric disasters that affect the agricultural field and beyond.

Stokols (1992) showed that the adoption of a healthier lifestyle can be transposed through the prism of care behavior and ecological behavior so that these benefits more precisely care for what we choose to consume; what we choose to produce creates another approach to anything that is around us and affects society as a whole with the benefits that flow from it [21].

The research helps to analyze any type of atypical disaster that can, according to the $\mathrm{S}_{\text {phor }}$ Index, strike agricultural systems, thus affecting ambitious carbon reduction targets. What we want to emphasize is the need to investigate the effect of electromagnetic waves on the ground; the progress of electromagnetic wave sampling reports and a map of them in relation to agricultural systems leads to the need to predict this through processes in order to give effective results.

Having these smart system options to adapt their agricultural systems to climate change through new technologies and digital systems for irrigation, pest control, and detection, fertilization is a breakthrough in agriculture. All this involves a volume of data that must be properly managed and prepared for data loss disasters; these data safes can generate electromagnetic radiation near the mobile systems of data cells.

As a consequence, we can say that from an economic point of view, the 2019 pandemic has exponentially increased the need and dependence on the use of digitalization agriculture, and possible disturbances and shocks of adverse climatic effects in agriculture add to the need for efficiency and standardization of smart agriculture monitoring all long-term process risks. The introduction of electromagnetic waves as a risk factor for disasters cannot be ruled out as long as atmospheric disturbances produce effects in agricultural ecosystems, which in turn generate carefully monitored greenhouse gases.

The new goal of a more equitable, greener, and more efficient CAP vision, which sup-ports environmental measures, also aims to strengthen the European agri-food system in line with the development of a greener agricultural system (Eurostat (2020)) [22]. 
Basically, this vision includes increased standards of conditionality that farmers must meet in order to benefit from CAP support, including the conservation of carbon-rich soils by protecting wetlands and peatlands as well as minimum levels of arable land for landscape features to protect biodiversity; see Antle (2007) [23].

In this sense, it is particularly important that the integration of these targets includes a risk analysis for other types of disasters such as electromagnetic waves to bring in the new CAP the performance flow of agricultural systems with customized development interventions to needs and strategy systems in accordance with the objectives envisaged at need.

Conflicts of Interest: The authors declare no conflict of interest.

\author{
Abbreviations \\ PAC Common Agricultural Policy \\ EEA European Environment Agency \\ Poluant atmosferic AIRPOL \\ ICNIRP Comisia internaţională de protecţie la radiaţii neionizante \\ ESS European Statistical System
}

\title{
References
}

1. Leal Filho, W.; Wu, Y.C.J.; Brandli, L.L.; Avila, L.V.; Azeiteiro, U.M.; Caeiro, S.; Madruga, L.R.D.R.G. Identifying and overcoming obstacles to the implementation of sustainable development at universities. J. Integr. Environ. Sci. 2017, 14, 93-108. [CrossRef]

2. Rodrigo-Comino, J.; Senciales, J.M.; Sillero-Medina, J.A.; Gyasi-Agyei, Y.; Ruiz-Sinoga, J.D.; Ries, J.B. Analysis of weather-typeinduced soil erosion in cultivated and poorly managed abandoned sloping vineyards in the Axarquía Region (Málaga, Spain). Air Soil Water Res. 2019, 12, 1178622119839403. [CrossRef]

3. Anderson, E.; Mammides, C. Changes in land-cover within high nature value farmlands inside and outside Natura 2000 sites in Europe: A preliminary assessment. Ambio 2020, 49, 1958-1971. [CrossRef] [PubMed]

4. Neill, S.D. McLuhan's media charts related to the process of communication. AV Commun. Rev. 1973, 21, 277-297. [CrossRef]

5. European Commission. Forging a Climate-Resilient Europe-The New EUStrategy on Adaptation to Climate Change. Second Pillar of the CAP: Rural Development Policy. 2021. Available online: https://www.europarl.europa.eu/factsheets/en/sheet/11 0/second-pillar-of-the-cap-ruraldevelopment-policy (accessed on 19 March 2021).

6. OECD. Towards Sustainable Land Use: Aligning Biodiversity, Climate and Food Policies; OECD Publishing: Paris, France, 2020. Available online: https://www.oecd-ilibrary.org/sites/3809b6a1-en/index.html?itemId=/content/publication/3809b6a1-en (accessed on 19 March 2021).

7. Girardin, P.; Bockstaller, C.; van der Werf, H. Indicators: Tools to Evaluate the Environmental Impacts of Farming Systems. J. Sustain. Agric. 1999, 13, 5-21. [CrossRef]

8. Aznar-Sánchez, J.A.; Piquer-Rodríguez, M.; Velasco-Muñoz, J.F.; Manzano-Agugliaro, F. Worldwide research trends on sustainable land use in agriculture. Land Use Policy 2019, 87, 104069. [CrossRef]

9. Greening the CAP. An Analysis of the Effects of the European Commission's Proposals for the Common Agricultural Policy. 2020. Available online: https:/ / oecd-environment-focus.blog/2020/12/23/securing-natural-capital-on-land/ (accessed on 19 March 2021).

10. Rayne, S.; Mazza, G. Biological Activities of Extracts from Sumac (Rhus spp.): A Review. Plant Foods Hum. Nutr. 2007, 62, 165-175. [CrossRef] [PubMed]

11. Andrei, A.; Robeson, M.S.; Baricz, A.I.; Coman, C.; Muntean, V.; Ionescu, A.; Etiope, G.; Alexe, M.; Sicora, C.I.; Podar, M.; et al. Contrasting taxonomic stratification of microbial communities in two hypersaline meromictic lakes. ISME J. 2015, 9, 2642-2656. Available online: https://link.springer.com/article/10.1007/s00606-020-01733-0 (accessed on 19 March 2021). [CrossRef] [PubMed]

12. The Intergovernmental Panel on Climate Change (IPCC). Available online: https:/ /www.epa.gov/climate-indicators/weatherclimate (accessed on 19 March 2021).

13. Food and Agriculture Organization. Feeding the World in 2050; World Summit on Food Security: Rome, Italy, 2016. Available online: http:/ / www.fao.org/tempref/docrep/fao/meeting/018/k6021e.pdf (accessed on 19 March 2021).

14. European Commission. Forging a Climate-Resilient Europe-The New EU Strategy on Adaptation to Climate Change, Brussels: COM 82. European Parliament, Second Pillar of the CAP: Rural Development Policy, Brussels. 2021. Available online: https: / / www.europarl.europa.eu/factsheets/en/sheet/110/second-pillar-of-the-cap-rural-development-policy (accessed on 19 March 2021).

15. FAO-WFP Early Warning Analysis of Acute Food Insecurity. According to the 2020 Global Report on Food Crises-September 2020. Available online: https:/ / reliefweb.int/report/yemen/fao-wfp-early-warning-analysis-acute-food-insecurity-hotspotsoctober-2020 (accessed on 19 March 2021). 
16. Popescu, L.; Safta, A.S. The Causal Relationship of Agricultural Standards, Climate Change and Greenhouse Gas Recovery. Environ. Sci. Proc. 2020, 4, 21. [CrossRef]

17. Air Pollutants by Source Sector (Source: EEA). Available online: https://appsso.eurostat.ec.europa.eu/nui/show.do?dataset= env_air_emis\&lang=en (accessed on 14 March 2021).

18. Directive 2001/81/EC of the European Parliament and the Council on National Emission Ceilings for Certain Pollutants (NEC Directive), Official Journal L 309. Available online: https:/ / eur-lex.europa.eu/legal-content/ES/ALL/?uri=CELEX:32001L0081 (accessed on 19 March 2021).

19. Lázaro, A. The Exponential Increase of Mobile Telephony Has Led to a Pronounced Increase in Electromagnetic Fields in the Environment That May Affect Pollinator Communities and Threaten Pollination as a Key Ecosystem Service. 2016. Available online: https: / /link.springer.com/article/10.1007/s10841-016-9868-8 (accessed on 14 March 2021).

20. Channels Are Frequently Accessed Using IEEE 802.11 Protocols, and Equipment That Does So Is Sold Mostly under the Trademark Wi-Fi. Available online: https:/ / en.wikipedia.org/wiki/List_of_WLAN_channelsWLAN (accessed on 19 March 2021).

21. Stokols, D. Establishing and maintaining healthy environments: Toward a social ecology of health promotion. Am. Psychol. 1992, 47, 6-22. [CrossRef] [PubMed]

22. Leal Filho, W.; Mandel, M.; Al-Amin, A.Q.; Feher, A.; Chiappetta Jabbour, C.J. An assessment of the causes and consequences of agricultural land abandonment in Europe. Int. J. Sustain. Dev. World Ecol. 2017, 24, 554-560. [CrossRef]

23. Antle, J.M.; Stoorvogel, J.; Valdivia, R. Assessing the economic impacts of agricultural carbon sequestration: Terraces and agroforestry in the Peruvian Andes. Agric. Ecosyst. Environ. 2007, 122, 435-445. Available online: https: / / www.academia.edu/23669686/Assessing_the_economic_impacts_of_agricultural_carbon_sequestration_Terraces_and_ agroforestry_in_the_Peruvian_Andes (accessed on 19 March 2021). [CrossRef] 